\title{
HARAPAN BAJULMATI EDUCATIONAL INSTITUTION AS ROLE MODEL FOR INTERFAITH HARMONY IN SOUTH MALANG
}

\author{
EDY S U TRIS N O \\ Kantor Kementerian Agama Kabupaten Malang Jl. Kolonel Sugiono No. 266 Malang Email: edyst99@gmail.com
}

\begin{abstract}
Education is a very appropriate tool, especially in using dynamic and inclusive religious values for everyone in society. Educational institutions are the main basis for shaping religious values in creating harmony between religious communities, therefore the model of harmony between religious communities can be applied in various community contexts. The purpose of this paper is to determine the Harapan Bajulmati educational institution as a role model for harmony between religious communities in South Malang. While the method in this writing uses descriptive qualitative methods. The results of this study are a role model of harmony between religious communities with education through educational institutions as the main basis for developing models of harmony between religious communities by means of a humanist and persuasive approach.
\end{abstract}

KEY WORDS: educational institution, role model, harmony

\section{LEMBAGA PENDIDIKAN HARAPAN BAJULMATI SEBAGAI ROLE MODEL KERUKUNAN ANTAR UMAT BERAGAMA DI MALANG SELATAN}

\begin{abstract}
Abstrak
Pendidikan menjadi sarana yang sangat tepat, khususnya di dalam menggunakan nilai-nilai agama yang dinamis dan inklusif bagi setiap orang yang berada dalam masyarakat. Lembaga pendidikan merupakan dasar utama dalam membentuk nilai-nilai agama dalam menciptakan kerukunan antar umat beragama, oleh karena itu model kerukunan antar umat beragama bisa diterapkan dalam konteks masyarakat yang beragam. Tujuan dalam penulisan ini adalah untuk mengetahui lembaga pendidikan Harapan Bajulmati sebagai role model kerukunan antar umat beragama di Malang Selatan. Sedangkan metode dalam penulisan ini menggunakan metode kualitatif deskriptif. Adapun hasil dalam penelitian ini adalah role model kerukunan antar umat beragama dengan edukasi melalui lembaga pendidikan sebagai basis utama dalam mengembangkan model kerukunan antar umat beragama dengan cara pendekatan humanis dan persuasif.
\end{abstract}

KATA KUNCI: lembaga pendidikan, role model, kerukunan

*Naskah diterima Agustus 2020, direvisi September 2020, dan disetujui untuk diterbitkan November 2020 


\section{A. Pendahuluan}

Letak Indonesia dari Sabang sampai Merauke memperlihatkan geografi kepulauan yang luas dengan kekayaan etnis yang sangat berlimpah (Widiastuti, 2013). Dampaknya, kekayaan alam khas untuk setiap daerah dan wilayah beragam. Secara sosiologis, fakta geografis itu ikut meyebabkan beragamnya etnik dan bahasa sesuai kebudayaan masing-masing wilayah dan daerah. Dari sisi manapun diamati, Indonesia adalah negara yang sangat penuh dengan kemajemukan. Termasuk dalam hal politik (Rahayu, 2017), dan terlebih keagamaan, dimana gereja berada di dalam kancah pluralisme dengan penganut agama lain dari Katolik, Buddha, Hindu, Islam, dan belakangan ini yang baru diterima sebagai agama resmi di Indonesi adalah Kong $\mathrm{Hu} \mathrm{Chu}$ (Soesilo, 2011). Kesimpulan yang dibuat Yewangoe sangat tepat, bahwa Indonesia merupakan sebuah negara majemuk dari segi manapun. Itulah yang menjadi kunci identitas Indonesia yang sejati (Yewangoe, 2002).

Berdasarkan fakta kemajemukan tersebut, setiap agama di Indonesia tidak dapat memungkiri fenomena pluralitas dan pengaruhnya dalam kehidupan bersama sebagai sesama warga negara. Di satu pihak, setiap agama dan pemeluknya, memiliki klaim normatif dan deskripsi yang bersifat apologetik mengenai ajaran, doktrin dan kebenaran absolut sesuai iman dan kepercayaannya. Di sisi lain, setiap agama dan pemeluknya harus memposisikan dirinya di dalam kerangka kemajemukan untuk menjamin keutuhan dan identitas keIndonesiaan tersebut (Lestari, 2016).

Persoalannya, sebagaimana konflik etnis dan agama yang menjadi tren di dalam kehidupan beragama di Indonesia belakangan ini, kemajemukan tersebut selain menjadi potensi yang baik di satu sisi juga menjadi pemicu lahirnya tindakan intoleransi akibat sikap penganut agama yang eksklusif, fanatik, dan merasa diri lebih dominan dibanding yang lain. Kasus-kasus yang muncul menyangkut kebenaran sektarian, benturan hal-hal normatif, fanatisme dan dominasi kekuasaan atas nama agama, membuktikan bahwa di balik kemajemukan yang terjadi, terdapat kerentanan yang berpotensi merusak kemajemukan itu sendiri ketika para pemeluk agama tidak mengikat diri dalam toleransi sehingga konflik terjadi (Halim \& Jambi,
2015). Terlebih jika dikaitkan secara politis, konflik-konfik horizontal yang terjadi atas nama agama menjadi tren belakangan ini di Indonesia. Penelitian Muhtadi yang dituangkan di dalam bukunya berjudul Populisme, Politik Identitas dan Dinamika Elektoral-Mengurai Jalan Panjang Demokrasi Prosedural, telah membuktikan fenomena tersebut (Muhtadi, 2019). Menguatnya politik identitas menjadi jalan terbuka bagi berbagai kepentingan di tengah realitas kemajemukan Indonesia. Demikian penelitian yang dibuat Zaluchu dan Widjaja, tentang maraknya penggunaan religious symbol di dalam politik menyatakan dengan terang benderang bahwa agama dengan sangat mudah ditunggangi oleh berbagai kepentingan (Zaluchu \& Widjaja, 2019), baik oleh kepentingan agama itu sendiri maupun oleh kepentingan eksternal.

Menyadari potensi kekuatan dan kelemahan di dalam kemajemukan berbangsa, bernegara, bersosialisasi dan berpolitik serta beragama di Indonesia, para founding father's bangsa ini telah menyediakan payung besar bagi keberagaman alamiah Indonesia, yang disebut Pancasila (Kirom, 2011). Payung tersebut menjadi platform bagi kemajemukan, dan menyediakan payung nilainiai luhur yang berada di atas dan melampaui perbedaan budaya, bahasa, etnis, wilayah dan agama di Indonesia. Keberadaannya membentuk nilai dan karakter sehingga sebagai falsafah dasar, perilaku orang Indonesia di dalam kemajemukan tetap memiliki "gaya sentrifugal yang mempertahankan keIndonesiaan secara internal (Nishimura, 1995). Sekalipun demikian, konflikkonflik horizontal bertemakan SARA, masih tetap saja menjadi persoalan simultan dan temporar di berbagai wilayah Indonesia (Fauzi, 2017), akibat kurangnya edukasi di dalam membentuk pemahaman keberagaman berdasarkan Pancasila di dalam rumah bersama yang bernama Indonesia (Raharjo et al., 2017).

Lembaga pendidikan merupakan dasar utama dalam membentuk nilai-nilai agama dalam menciptakan kerukunan antar umat beragama, seperti halnya pendidikan yang ada di Malang Selatan, Meskipun sarana pendidikan tampak seperti "laskar pelangi" apa adanya dan tidak mementingkan fasilitas yang mewah, namun nilai-nilai kemanusiaan dan kesamaan harkat dan martabat manusia dibangun dari lembaga pendidikan ini. Kultur peserta didiknya menganut 
kepercayaan yang berbeda agama seperti Hindu, Buddha, Kristen, dan Islam. Lembaga yang bernapaskan Islam tetapi peminatnya dari beberapa agama dengan kehidupan yang rukun dan damai.

Dari Latar belakang di atas penulis mengambil judul Lembaga Pendidikan Harapan Bajulmati Sebagai Role Model Kerukunan Hidup Antar Umat Beragama di Malang Selatan dengan rumusan masalah bagaimana lembaga pendidikan Harapan Bajulmati sebagai role model kerukunan hidup antar umat beragama di Malang Selatan.

\section{B. Metode Penelitian}

Penelitian ini dilaksanakan pada masyarakat Bajulmati Kecamatan Gedangan Malang. Tepatnya di Lembaga Pendidikan Harapan Bajulmati. Di Bajulmati ini terdapat 4 Agama yang dianut, yaitu agama Islam, Kristen, Buddha, dan Hindu. Kegiatan penelitian dilaksanakan pada bulan Juli-Desember 2019, dengan pengumpulan data lapangan dilakukan bulan Januari dan Maret 2020.

Pendekatan dalam penelitian menggunakan pendekatan case study yang mencoba memahami nilai-nilai hidup dari subjek penelitian. Oleh karenanya, dalam penelitian ini metode penelitian yang dipakai adalah metode kualitatif. Menurut Strauss dan Corbin, penelitian kualitatif merupakan penelitian yang dapat digunakan untuk meneliti kehidupan masyarakat, sejarah, tingkah laku, fungsionalisasi organisasi, gerakan sosial, atau hubungan kekerabatan. Sementara itu, menurut Bogdan dan Taylor, bahwa penelitian kualitatif merupakan prosedur penelitian yang mampu menghasilkan data deskriptif berupa ucapan, tulisan, dan perilaku dari orang-orang yang diamati (Nugrahani \& Hum, 2014).

Sumber data primer dalam penelitian ini adalah data-data hasil riset di lapangan, baik dalam bentuk hasil wawancara mendalam, catatan observasi, maupun data dokumentasi. Wawancara dipergunakan untuk mendalami persoalan-persoalan penelitian yang ditujukan pada subjek penelitian atau narasumber yang dipilih (representative informant). Subjek penelitian ini adalah masyarakat yang terdiri dari penggagas berdirinya lembaga pendidikan Harapan Bajulmati, Guru di lembaga pendidikan Harapan Bajulmati baik RA, TK, PAUD, dan SD, tokoh agama, dan warga sekitar Bajulmati, yang dipandang representatif untuk memberi informasi terkait tema penelitian ini. Observasi atau pengamatan dipergunakan untuk mendapatkan gambaran langsung dari sasaran yang diteliti, meliputi suasana baik fisik maupun psikis, prosesi, dan perilaku pihak-pihak terlibat dalam lembaga pendidikan yang diteliti. Adapun dokumentasi digunakan untuk mendapatkan data-data dengan cara mengumpulkan dokumen-dokumen yang telah terdokumentasikan dan atau mendokumentasikan kejadian-kejadian, peristiwa-peristiwa yang berkaitan dengan kepentingan penelitian.

Metode analisis data yang digunakan dalam penelitian ini adalah metode analisis deskriptif (descriptive analysis) dan analisis reflektif (reflective analysis) yakni mengungkap situasi yang dikaji, relasi-relasi sosial yang berperan, dan pengaruhpengaruh yang bisa ditimbulkan dari hubungan tersebut. Proses analisis ini dilakukan secara terus menerus (constant), secara sadar, dan cermat, sehingga hasil penelitian ini bersifat deskriptifeksplanatif, yang merupakan salah satu ciri khas dari penelitian kualitatif. Analisis ini juga digunakan untuk mengelaborasi pemikiran yang lebih jelas tentang role model kerukunan antar umat beragama di Malang Selatan.

\section{Hasil dan Pembahasan Konsep Kerukunan Antar Umat Beragama}

Dalam pengertian sehari-hari kata rukun dan kerukunan adalah damai dan perdamaian. Dengan pengertian ini jelas, bahwa kata kerukunan hanya dipergunakan dan berlaku dalam dunia pergaulan. Kerukunan antar umat beragama adalah cara atau sarana untuk mempertemukan, mengatur hubungan luar antara orang yang tidak seagama atau antara golongan umat beragama dalam kehidupan sosial kemasyarakatan. Istilah kerukunan umat beragama pertama kali dikemukakan oleh Menteri Agama, K.H. M. Dachlan, dalam pidato pembukaan Musyawarah Antar Agama tanggal 30 Nopember 1967 antara lain menyatakan: Adanya kerukunan antara golongan beragama adalah merupakan syarat mutlak bagi terwujudnya stabilitas politik dan ekonomi yang menjadi program kabinet AMPERA. Oleh karena itu, kami mengharapkan sungguh adanya kerjasama antara pemerintah dan 
masyarakat beragama untuk menciptakan iklim kerukunan beragama ini, sehingga tuntutan hati nurani rakyat dan cita-cita kita bersama ingin mewujudkan masyarakat yang adil dan makmur yang dilindungi Tuhan Yang Maha Esa itu benar-benar dapat berwujud. Dari pidato K.H. M. Dachlan tersebutlah istilah "Kerukunan Hidup Beragama" mulai muncul dan kemudian menjadi istilah baku dalam berbagai dokumen negara dan peraturan perundang-undangan (Rusydi \& Zolehah, 2018).

Kata kerukunan dari kata rukun berasal dari bahasan Arab ruknun (rukun) yang berjamak arkan berarti asas atau dasar, misalnya: rukun Islam berarti asas Islam atau dasar agama Islam (Luthfi, 2017). Sementara, istilah "kerukunan" dalam Kamus Besar Bahasa Indonesia yang diterbitkan oleh Departemen Pendidikan dan Kebudayaan, diartikan sebagai "hidup bersama dalam masyarakat dengan "kesatuan hati" dan "bersepakat" untuk tidak menciptakan perselisihan dan pertengkaran". Kerukunan adalah istilah yang dipenuhi oleh muatan makna "baik" dan "damai". Intinya, hidup bersama dalam masyarakat dengan "kesatuan hati" dan "bersepakat" untuk tidak menciptakan perselisihan dan pertengkaran (Rusydi \& Zolehah, 2018).

Dalam pasal 1 angka (1) peraturan bersama Menteri Agama dan Menteri Dalam Negeri No. 9 dan 8 Tahun 2006 tentang Pedoman Pelaksanaan Tugas Kepala Daerah/Wakil Kepala Daerah dalam pemeliharaan kerukunan umat beragama, pemberdayaan forum kerukunan umat beragama, dan pendirian rumah ibadat dinyatakan bahwa: Kerukunan umat beragama adalah keadaan hubungan sesama umat beragama yang dilandasi toleransi, saling pengertian, saling menghormati, menghargai kesetaraan dalam pengamalan ajaran agamanya dan kerjasama dalam kehidupan bermasyarakat, berbangsa dan bernegara di dalam Negara Kesatuan Republik Indonesia berdasarkan Pancasila dan Undang-Undang Dasar Negara Republik Indonesia Tahun 1945.

Mencermati pengertian kerukunan umat beragama, tampaknya peraturan bersama di atas mengingatkan kepada bangsa Indonesia bahwa kondisi ideal kerukunan umat beragama, bukan hanya tercapainya suasana batin yang penuh toleransi antar umat beragama, tetapi yang lebih penting adalah bagaimana mereka bisa saling bekerjasama. Jadi dapat disimpulkan bahwa kerukunan ialah hidup damai dan tentram saling toleransi antara masyarakat yang beragama sama maupun berbeda, kesediaan mereka untuk menerima adanya perbedaan keyakinan dengan orang atau kelompok lain, membiarkan orang lain untuk mengamalkan ajaran yang diyakini oleh masing-masing masyarakat, dan kemampuan untuk menerima perbedaan. Kerukunan berarti sepakat dalam perbedaan-perbedaan yang ada dan menjadikan perbedaan-perbedaan itu sebagai titik tolak untuk membina kehidupan sosial yang saling pengertian serta menerima dengan ketulusan hati yang penuh ke ikhlasan. Kerukunan mencerminkan hubungan timbal balik yang ditandai oleh sikap saling menerima, saling mempercayai, saling menghormati, dan menghargai, serta sikap saling memaknai kebersamaan. Berdasarkan pemaparan di atas maka pengertian dari kerukunan umat beragama adalah kondisi dimana antar umat beragama dapat saling menerima, saling menghormati keyakinan masing-masing, saling menolong, dan bekerjasama dalam mencapai tujuan bersama (Rusydi \& Zolehah, 2018).

Secara teologis, sikap dan pandangan seseorang tentang kehidupan beragama akan lebih toleran bila ia memiliki pandangan teologis yang bisa menerima perbedaan dan mendukung toleransi kehidupan beragama. Sebagaimana pendapat Yusuf, dalam tulisannya yang berjudul: Islamic Theology of Religious Pluralism; Qur'an's Attitude Toward Other Religion menjelaskan teologi kerukunan yang didasarkan atas sejumlah proposisi yang diambil dari ajaran al-Qur'an. Proposisi pertama: Allah and other definition of ultimate reality are identical in essence (Allah dan definisi lain tentang realitas tertinggi pada esensinya adalah sama). Proposisi ini diambil dari surat al-Ankabut (29) ayat 46. Proposisi kedua, Diversity of religion is part of God's plan and will last as long as the world last (Pluralitas agama merupakan bagian dari rencana Tuhan sehingga akan terus ada sampai kiamat). Proposisi ini diambil dari surat al-Maidah (5) ayat 48. Proposisi ketiga: Muslim must be tolerant and reverential toward other religions (Muslim mesti toleran dan menghormati agama-agama lain). Proposisi ini diambil dari surat al-Baqarah (2) ayat: 256, surat al-Kahfi (18) ayat 29, dan surat al-Kafirun (109) 
ayat: 6. Proposisi keempat: Everyone who believes in Ultimate Reality and does goods guaranteed salvation (Setiap orang yang percaya akan Realitas Tertinggi dan melakukan pekerjaan yang baik maka ia akan terjamin keselamatannya). Proposisi ini diambil dari surat al- Baqarah (2) ayat 62 dan surat al-Maidah (5) ayat:69. Proposisi kelima: Islam is not a new religion but are confirmation of truth revealed before. Muslims believe in all prophets without making any distinction between them (Islam bukan agama yang baru melainkan konfirmasi bagi kebenaran wahyu sebelumnya. Muslim mempercayai semua para nabi tanpa membedakan satu dan lainnya). Proposisi ini diambil dari surat al-Baqarah (2) ayat 285, surat Ali Imran (3) ayat 84, surat al-Nisa (4) ayat 163. Proposisi keenam: A need of reinterpretation, so Islam understood in more inclusive way (Diperlukan adanya reinterpretasi sehingga Islam bisa dipahami dengan cara lebih inklusif. Proposisi ini diambil dari surat ali Imran (3) ayat 19 dan ayat 85 (Yusuf, 2010).

Pendapat tersebut dikuatkan oleh Syarif, dalam tulisannya yang berjudul: Teologi Kerukunan, yang menjelaskan enam pedoman sebagai berikut. Pertama, umat beragama harus bisa menerima dengan ikhlas adanya perbedaan di antara mereka, karena perbedaan itu merupakan bagian dari "rencana" Tuhan (QS. 5: 48). Kedua, tidak boleh ada intimidasi atau pemaksaan dalam urusan agama dan keyakinan (QS. 2: 256). Ketiga, umat beragama tidak boleh menghina satu sama lain karena perbedaan sistem keyakinan yang dimilikinya (QS. 6:108). Keempat, karena dalam hal sesat menyesatkan pada akhirnya Tuhan yang paling tahu, maka sebaiknya urusan ini diserahkan saja kepada Tuhan yang akan memutuskannya (QS. 6:159 dan QS. 16:125). Barangkali tuduhan atau klaim dari satu kelompok bahwa kelompoknyalah yang benar sementara yang lain sesat, mungkin tidak bisa dihilangkan sama sekali dari wacana keagamaan. Namun setidaknya wacana ini tidak boleh digunakan untuk menghilangkan hak kelompok lain untuk menjalankan ibadah atau mengekspresikan keyakinan agamanya, sebab kebebasan ini dilindungi oleh konstitusi. Kelima, tentang urusan keselamatan di akhirat atau surga, juga hendaknya tidak dijadikan pertentangan yang sengit di antara umat beragama, karena sebagaimana urusan sesat menyesatkan, urusan surga dan neraka juga pada akhirnya merupakan hak prerogatif Tuhan (QS. 2: 62 dan QS. 5:69). Keenam, semua umat beragama hendaknya samasama menjunjung tinggi nilai kemanusiaan universal, karena semua manusia pada dasarnya sama sebagai anak Adam yang dimuliakan Tuhan (QS. 49: 9-13) (Syarif, 2013).

Islam menjunjung tinggi toleransi. Toleransi mengarah kepada sikap terbuka dan mau mengakui adanya berbagai macam perbedaan, baik dari sisi suku bangsa, warna kulit, bahasa, adat-istiadat, budaya, bahasa, serta agama. Ini semua merupakan fitrah dan sunnatullah yang sudah menjadi ketetapan Tuhan. Dalam terminologi Islam, istilah yang dekat dengan kerukunan umat beragama adalah "tasamuh". Keduanya menunjukkan pengertian yang hampir sama, yaitu saling memahami, saling menghormati, dan saling menghargai sebagai sesama manusia. Tasamuh memuat tindakan penerimaan dan tuntutan dalam batas-batas tertentu. Dengan kata lain, perilaku tasamuh dalam beragama memiliki pengertian untuk tidak saling melanggar batasan, terutama yang berkaitan dengan batasan keimanan (aqidah).

Konsep toleransi beragama dalam Islam bukanlah membenarkan dan mengakui semua agama dan keyakinan yang ada saat ini, karena ini merupakan persoalan aqidah dan keimanan yang harus dijaga dengan baik oleh setiap pribadi muslim. Toleransi bukan mengakui semua agama sama, apalagi membenarkan tata cara ibadah umat beragama lain. Tidak ada toleransi dalam hal aqidah dan ibadah. Karena sesungguhnya bagi orang Islam agama yang diridhai di sisi Allah hanyalah Islam. Toleransi hanyalah dalam urusan muamalah dan kehidupan sosial (Rusydi \& Zolehah, 2018).

\section{Makna Interaksi Sosial Keagamaan}

Secara garis besar hubungan antar atau intern umat beragama bisa dibagi menjadi dua. Pertama, mereka yang memiliki pandangan keagamaan yang inklusif, toleran dan humanis. Kedua, mereka yang memiliki pandangan keagamaan yang eksklusif, intoleran dan otoritarian. Pandangan keagamaan disebut inklusif bila ia masih memberikan kemungkinan akan adanya kebenaran dan keselamatan pada penganut agama atau aliran lainnya. Sebaliknya pandangan keagamaan disebut eksklusif bila ia hanya 
mengakui kebenaran dan keselamatan kelompoknya sendiri.

Sedangkan pandangan yang toleran bisa diukur bila ia memenuhi enam kriteria toleran sebagaimana disebutkan di atas. Orang yang memiliki pandangan keagamaan yang inklusif cenderung lebih toleran dibandingkan dengan orang yang memiliki pandangan keagamaan yang eksklusif. Akan tetapi baik mereka yang memiliki pandangan keagamaan eksklusif maupun inklusif belum tentu bersikap otoriter. Problem intoleransi seringkali muncul dari sikap-sikap arogan yang akan memaksakan pandangannya sendiri termasuk melalui cara-cara kekerasan. Dalam kondisi seperti ini, agama tidak akan menampilkan wajahnya yang humanis tapi akan menampilkan wajahnya yang otoritarian.

Istilah Authoritarianism dalam pandangan Abou El-Fadl, adalah "The act of "locking" or captivating the Will of the Divine, or the will of the text, into a specific determination, and then presenting this determination as inevitable, final and conclusive (Abou El Fadl, 2014). Otoritarianisme adalah tindakan penguncian atau menawan kehendak Ilahi atau kehendak teks ke dalam penentuan tertentu sebagai tak terelakkan, final dan konklusif. Orang yang memahami agama secara otoriter pada dasarnya telah mengunci atau menawan kehendak llahi atau kehendak teks sesuai dengan kehendaknya sendiri. Atau dengan kata lain, dia telah memonopoli akses terhadap Tuhan.

Respon atau sikap umat beragama terhadap penganut agama lain dipengaruhi oleh pandangan keagamaannya. Orang yang memiliki pandangan keagamaan yang inklusif, toleran, dan humanis akan berbeda dengan orang yang memiliki pandangan keagamaan yang eksklusif, intoleran, dan otoritarian. Jadi, pandangan keagamaan mempengaruhi sikap keagamaan.

Dalam konteks Indonesia, upaya menciptakan kerukunan umat beragama dikenal dengan sebutan trilogi kerukunan umat beragama, yakni: 1) kerukunan intern umat beragama 2) kerukunan antar umat beragama 3) kerukunan antar umat beragama dengan pemerintah.

\section{Pentingnya Kerukunan Antar Umat Beragama}

Sejak Konsili Vatikan II, sebagaimana ungkapan Scultheis, pernyataan-pernyataan Paus
Paulus VI dan Yohanes Paulus II, sinode para uskup, dan konferensi-konferensi para uskup regional maupun nasional semakin mempertajam peranan Gereja dalam tanggung jawab terhadap dunia yang sedang berubah dengan pesat ini. Kedua paus dan para uskup itu sepenuhnya sadar bahwa mencari kehendak Allah dalam arus sejarah dunia bukanlah tugas yang sederhana. Mereka juga menyadari bahwa Gereja tidak mempunyai pemecahan yang langsung dan secara universal sahih untuk memecahkan masalah-masalah masyarakat yang kompleks. Dalam dokumen kedua yang secara khusus memberi sumbangan mengenai tanggung jawab di atas adalah berupa surat apostolik, octogesima adveniens yang ditulis Paus Paulus VI tahun 1971 untuk merayakan 80 tahun dokumen rerum novarum. Dalam surat ini diketengahkan bahwa kesulitan menciptakan tatanan baru melekat dalam proses pembangunan tatanan itu sendiri, sekaligus Paulus VI menegaskan peranan jemaatjemaat kristiani dalam mengemban tanggung jawab baru ini. "terserahlah kepada jemaat-jemaat kristiani untuk menganalisa secara obyektif situasi yang khas dalam negaranya sendiri, menyinarinya dengan terang kata- kata injil yang tak pernah berubah dan menyusun prinsip-prinsip untuk refleksi, normanorma pertimbangan serta pegangan bertindak dari ajaran sosial Gereja" (Luthfi, 2017).

Hukum-hukum di atas menyatakan bahwa manusia mempunyai hak penuh dalam berbudaya. Bahkan, diperintahkan untuk di setiap gereja menyebarkan injil mempergunakan bentuk-bentuk kebudayaan. Di sinilah bentuk inkulturasi agama dengan kebudayaan dalam Kristen. Dalam hukum-hukum seperti di atas disebutkan dengan Gereja sebagai subyek Agama Kristen dalam menyebarkan agama.

Dalam catatan Armada, kedudukan Gereja dalam tata keselamatan manusia tidak berubah, ia tetap merupakan sekramen keselamatan Yesus. Apa saja yang berubah atau lebih tepatnya berkembang ialah cara pandang Gereja terhadap dunia, manusia, dan agama-agama. Bila penegasan tradisional (sebelum Konsili Vatikan II) tentang paham Gereja lebih cenderung menonjolkan semangat Triumpalish, maka pandangan Gereja setelah Konsili Vatikan II lebih cenderung diagonal. Dalam berkata tentang apaapa yang baik dalam diri sendiri Gereja tidak lagi memakai cara yang lama, dengan memandang 
kurang baik terhadap yang lain. Dewasa ini Gereja telah sampai pada penemuan diri, yaitu dengan memandang agama-agama lain selain Kristen secara positif. Dengan demikian menegaskan kembali posisi Gereja dalam keselamatan manusia tidak dimaksudkan untuk mencari keunggulan gereja di antara agama-agama lain, sebaliknya merupakan cara mengaktualisasikan diri dalam kurun pluralisme agama dewasa ini (Luthfi, 2017). Jelas sekali di atas bahwa Gereja sangat sadar betul dewasa ini bahwa kerukunan antar umat beragama menjadi hal yang paling utama untuk diprioritaskan melebihi prioritas apapun di dalam ajaran agama.

Begitu juga dengan Islam sebagaimana yang kita ketahui, bahwa banyak sekali tokoh-tokoh Islam seperi Abdurrahman Wahid atau Nurcholis Majid di mana semasa hidup beliau selalu menggaung-gaungkan ajaran pluralisme atau kerukunan antar umat beragama sebagai dasar negara Indonesia supaya menjadi negara yang kuat dan damai. Dalam pendapat Abdul Aziz Thoba, (1996) sifat ajaran Islam sangatlah terbuka, ia menerima pengaruh adat, tradisi, dan kepercayaan-kepercayaan lama, dan inilah yang mempercepat proses Islamisasi (Luthfi, 2017).

\section{Mengembangkan Konsep Kerukunan dengan Edukasi}

Sila pertama dari Pancasila adalah sebuah cerminan dari adanya ruang yang sangat luas bagi terciptanya kerukunan beragama di Indonesia. Hasil penelitian Pratiwi dan Rosidi menyatakan bahwa sesungguhnya sila pertama dari Pancasila, sudah sangat cukup memberi aturan yang tegas mengenai kerukunan antar umat beragama. Adapun penyebab konflik yang melibatkan agama, lebih dipicu oleh rendahnya kesadaran para penganut agama untuk mempertahankan dirinya di dalam aturan falsafah dasar tersebut (Daeli \& Zaluchu, 2019). Hal inilah yang menjadi tantangan bersama bahwa nilai-nilai kerukunan beragama hanya dapat ditegakkan dengan jalan edukasi. Menurut Jauhari, kemajemukan hanya dapat bertahan melalui pengelolaan yang benar. Pendidikan menjadi sarana yang sangat tepat, khususnya di dalam menggunakan nilai-nilai agama yang dinamis dan inklusif bagi setiap orang yang berada di dalamnya (Jauhari, 2017).

Langkah terpenting di dalam edukasi adalah membentuk konsep yang benar tentang kerukunan. Istilah "kerukunan" jauh lebih positif dan dinamis ketimbang istilah "toleransi" yang statis. Toleransi lebih mengisyaratkan adanya persetujuan satu pihak untuk memberi hak hidup kepada pihak lain. Artinya keberadaan satu pihak hanya dapat terjadi antara pihak lain menghendakinya. Andaikata satu pihak tidak berkenan, maka pihak lain dapat dengan mudah dieliminasi. Sedangkan "kerukunan" mengandung pengertian bahwa walaupun saling berbeda, kedudukan dan posisinya tidak saling mengungguli, satu di atas yang lain. Kerukunan tidak mengenal istilah subordinasi atas nama agama di kalangan penganutnya. Hak-hak dan kewajibannya setara. Terlebih untuk hidup, di dalam kerukunan, seseorang tidak perlu bergantung pada izin orang lain. Kerukunan justru mengisyaratkan konsep saling tergantung antar individu yang bersifat menguatkan kesatuan (Mawardi, 2015).

Hasil penelitian yang dilakukan oleh Maftukhah berjudul Kerukunan Antar-umat Beragama Dalam Masyarakat Plural, dapat dijadikan acuan untuk menarik kesimpulan (Maftukhah, 2014). Pendekatan yang dipergunakannya adalah ekspresi keragaman yang disusun dalam tiga kelompok, yakni eksklusivisme, inklusifisme, dan pluralisme (Daeli \& Zaluchu, 2019). Maftukhah mengusulkan pluralisme sebagai jawaban karena keberagamaan merupakan realitas yang tidak dapat ditolak atau ditiadakan. Muncul konsekuensi logis dari cara hidup orang di dalam menjalani agamanya di dalam keberagamaan, yakni hidup berdampingan dengan damai. Studi yang dilakukannya di Dusun Losari, Kabupaten Magelang, yang memiliki tiga bangunan berdekatan tempat ibadah dari penganut tiga agama yang berbeda yakni masjid, gereja Katolik, dan vihara Trinarmada. Konflik horizontal tidak pernah terjadi di desa tersebut. Penduduk desa mengembangkan kehidupan yang rukun dan komunikasi yang sehat antar-warga. Melalui hubungan antar-warga yang saling menghargai dan menghormati, integrasi ke dalam kesatuan terbentuk dengan mudah.

\section{Role Model Kerukunan Antar Umat Beragama}

Role model adalah orang yang perilakunya, atau keberhasilannya dapat ditiru oleh orang lain, terutama oleh orang-orang yang lebih muda. Role model bisa diartikan juga dengan seseorang yang 
terhormat.

Dalam teori belajar sosial, konsep suatu model dalam pengertian ini memainkan peranan penting karena sebagian besar sosialisasi diasumsikan berlangsung lewat pengimitasian perilaku model panutan. Role model adalah bagian dari teori modelling Bandura (1986). Menurut Bandura, pembelajaran yang berasal dari sumber tidak langsung seperti mendengar atau observasi disebut vicarious learning. Vicarious learning adalah proses belajar yang dilakukan seseorang ketika mengamati tindakan dan perilaku orang lain dan konsekuensi dari perilaku tersebut. Sehingga seseorang dapat mempelajari perilaku dengan mengamati perilaku orang lain dan konsekuensi dari perilaku tersebut. Bandura membedakan dua fungsi utama dalam modelling yaitu: Pertama, pemfasilitasan respon (response facilitation) artinya dorongan-dorongan sosial menciptakan ajakanajakan bagi pengamat untuk mengikuti tindakantindakan (mengikuti apa yang dilakukan orang banyak).

Kedua, hambatan atau penghilangan hambatan (inhibition/disinhibition) adalah tindakan-tindakan yang dimodelkan menciptakan harapan-harapan dalam diri pengamat untuk mengalami akibat-akibat yang serupa jika mereka melakukan tindakan-tindakan tersebut, dan pembelajaran observasional (observational learning) merupakan proses-proses yang meliputi perhatian, pemertahanan, produksi dan motivasi.

Teori belajar sosial lain dari Akers (1998) menjelaskan empat konsep yang saling berkaitan, yaitu differential association, definitions, differential reinforcement and imitation. Mekanisme dasar dari teori belajar sosial di antaranya: (1) Dengan mengadopsi yang menguntungkan perilaku yang ada melalui hubungan diferensial dengan orangorang di sekitarnya. (2) Dengan meniru perilaku orang di sekitarnya. (3) Melalui penguatan positif yang diberikan lewat imbalan (Simon, 2017).

Sedangkan dalam pandangan Snelbecker, pengertian model sendiri diartikan sebagai perwujudan suatu teori atau wakil dari proses dan variabel yang mencakup dalam teori, begitu pula Horton seperti yang dikutip oleh Suriasumantri, mengemukakan bahwa model bersifat menjelaskan hubungan berbagai komponen, aksi dan reaksi, serta sebab akibat. Lebih jelas lagi dinyatakan bahwa model biasanya digunakan untuk hal-hal yang bersifat menggambarkan sesuatu, menjelaskan suatu proses, mengkaji atau menganalisis sesuatu sistem, menggambarkan suatu kejadian, dan bersifat memprediksikan suatu keputusan yang akan diambil. Sejalan dengan pernyataan tersebut, Briggs dalam Gafur berpendapat bahwa model adalah seperangkat prosedur yang berurutan untuk mewujudkan suatu proses kerja. Hampir semua cara pengembangan pembelajaran dinyatakan dalam bentuk model dengan alasan: (a) agar mudah dikomunikasikan kepada para calon pemakai, (b) dapat memperlihatkan tugas-tugas utama yang harus dikerjakan dan arena itu berguna sekali untuk keperluan pengelolaan, dan (c) memperlihatkan struktur semacam matriks di mana tujuan belajar dan strategi belajar dapat diperbandingkan dan disesuaikan. Jadi, yang dimaksud dengan model adalah suatu kerangka konseptual yang bersifat prosedural berupa sebuah pola atau rancangan yang dapat digunakan sebagai acuan dalam pengembangan program kegiatan dalam rangka mempertahankan kerukunan sosial dalam masyarakat. Pengembangan model kerukunan sosial dalam perspektif agama adalah perwujudan dari teori multikulturalisme, teori interaksi sosial, akulturasi dan amalgamansi (Arif, 2014).

Kerukunan itu sendiri merupakan istilah yang sarat dengan makna "baik" dan "damai". Kerukunan berkonotasi sebagai kehidupan bersama dalam masyarakat dengan "kesatuan hati" dan "bersepakat" untuk tidak menciptakan perselisihan dan pertengkaran. Bila pemaknaan tersebut dijadikan pegangan, maka "kerukunan" adalah sesuatu yang ideal dan didambakan oleh masyarakat manusia. Kerukunan secara luas bermakna adanya suasana persaudaraan dan kebersamaan antar semua orang walaupun mereka berbeda secara suku, agama, ras, dan golongan. Selain bermakna sebagai kemampuan dan kemauan untuk hidup berdampingan dan bersama dengan damai serta tenteram, kerukunan juga bermakna sebagai proses untuk menjadi rukun karena sebelumnya ada ketidakrukunan. Untuk mencapai kerukunan seperti itu, tentu diperlukan adanya proses dialog, saling terbuka, saling menerima, saling menghargai, serta saling menanamkan rasa cinta-kasih.

Dari penjelasan di atas telah jelas bahwa Pancasila dan juga Undang- Undang Dasar 1945 adalah sebagai hukum dan juga model dasar 
kerukunan antar umat beragama yang ada di seluruh Indonesia. Namun begitu dalam pelaksanaannya di berbagai daerah yang majemuk dan beraneka ragam, mempunyai model-model tertentu sebagai alat untuk mempersatukan antar umat beragama, seperti paguyuban antar pemeluk agama, perkumpulan adat dan sebagainya. Misalnya penelitian yang dilakukan oleh Joko Tri Hartanto tentang pola kerukunan umat beragama di Singkawang bahwa interaksi sosial yang dilakukan oleh masyaraat Singkawang sangat erat kaitanya antara agama dengan budaya. Agama kooperatif dengan budaya yang paling menonjol adalah dalam dimensi sosial atau kemasyarakatan. Dalam dimensi ini agama mendorong sikap menghormati orang lain, bekerjasama dalam kebaikan, dan tolong menolong. Sebagai contoh tradisi Naik Dangau yang diselenggarakan oleh etnis Dayak, bagi yang beragama Kristen atau Katolik dilakukan misa tersendiri sebelum perayaan Naik Dangau (Luthfi, 2017)

Begitu juga dengan agama Islam, terutama dalam pendidikan. Misalnya, madrasah merupakan lembaga pendidikan agama Islam yang di dalam kurikulumnya madrasah sebagai lembaga pendidikan dan pengajaran agama Islam sebagai kelanjutan dari pendidikan dan pengajaran agama sebelumnya, seperti langgar, surau, rangkang. Dan dapat dikatakan bahwa Madrasah merupakan bentuk atau wujud baru dalam pendidikan Islam di Indonesia (Nata, 2001).

Salah satu dari cara para penyebar Islam di tanah Jawa adalah dengan menggunakan ideologi. Dimana para ulama harus menciptakan mitos dan nilai-niai tandingan baru yang sesuai dengan Islam. Salah satu tugas utama para ulama yang telah dikader oleh Raden Rakhmat adalah menyebarkan dengan membentuk nilai ma-lima yang menyerupai Yoga-Tan-Tra dalam agama.

Dikisahkan pada suatu hari Sunan Kudus pernah mengikat seekor lembu yang didandani dengan sangat istimewa di halaman masjid Kudus, sehingga masyarakat sekitar yang pada waktu itu masih memeluk agama Hindu datang berduyun-duyun untuk menyaksikan lembu yang didandani dengan sangat mewah dan aneh tersebut. Sesudah mereka datang dan berkerumun di sekitar masjid, barulah Sunan Kudus menyampaikan dakwahnya. Cara ini juga sangatlah efektif dimana diketahui bahwa lembu adalah binatang yang disucikan oleh umat Hindu, dan Sunan Kudus tidak menghinakanya, bahkan memuliakanya dengan beliau bertitah pada waktu itu melarang umat muslim menyembelih lembu. Dan akhirnya Sunan Kudus berhasil mengislamkan masyarakat di kadipaten Kudus (Sofwan et al., 2000). Wayang kulit, seperti yang dapat kita nikmati sekarang ini, juga merupakan buah inkulturasi, sebuah karya berupa kompromi. Dalam Islam, manusia tidak boleh dipatungkan atau disimbolkan seperti berupa gambar. Sedang tradisi Hindu dan Buddha adalah mematungkan Dewa dan Sang Buddha. Kisah Mahabharata dan Ramayana juga dilukiskan di atas kulit atau kain. Wayang kulit yang ditonton di balik layar tentu bukan patung, dan juga bukanlah lukisan. Karena yang membawa masuk Islam ke tanah Jawa begitu beragam, Sunan Kalijaga, yang paling muda dari sembilan wali penyebar Islam di tanah Jawa, yang juga ber-etnis Cina, merasa kesulitan dalam "meng-Islamkan" orang-orang Jawa. Maka ia meminta beberapa muridnya untuk menaruh gamelan di halaman masjid dan menabuhnya. Orang-orang pun mulai berdatangan demi mendengarkan alunan gamelan yang dimainkan itu. Lewat gamelan dan Wayang (Hindu) itulah Sunan Kalijaga menyapa dan mengajak mereka memeluk Islam (Luthfi, 2017).

Di Jogja ada tradisi Grebeg, berasal dari kata "gumrebeg" yang berarti riuh dan ramai. Itu menggambarkan suasana meriah penuh gairah (ghirah) masyarakat sepanjang perayaan Grebeg. Masyarakat Jogja dan kota-kota sekitarnya tumplek di Alun-alun Utara Jogja. Grebeg adalah upacara adat berupa sedekah yang dilakukan pihak kraton kepada masyarakat berupa gunungan. Kraton Yogyakarta dan Surakarta setiap tahun mengadakan upacara Grebeg sebanyak 3 kali, yaitu Grebeg Syawal pada saat hari raya Idul Fitri, Grebeg Besar pada saat hari raya Idul Adha, dan Grebeg Maulud atau sering disebut dengan Grebeg Sekaten pada peringatan Maulid Nabi Muhammad (Luthfi, 2017).

Pancasila merupakan pilar kehidupan bangsa Indonesia. Keberadaan Pancasila sudah seharusnya mampu direfleksikan secara kritis akan arti penting Pancasila sebagai pedoman hidup dan falsafah kehidupan bangsa Indonesia dalam upaya proses merajut kerukunan bangsa dan negara. Pancasila sebagai upaya membimbing umat manusia Indonesia ke arah kebajikan dan 
kebenaran dan bertindak. Pancasila merupakan pandangan dunia (way of life), pandangan hidup (weltanschauung), petunjuk hidup (wereld en levens beschouwing). Pancasila harus diamalkan dalam kehidupan sehari-hari, dengan kata lain, Pancasila digunakan sebagai petunjuk arah semua kegiatan dan aktivitas hidup, dan kehidupan di dalam segala bidang, politik, pindidikan, agama, budaya, sosial, dan ekonomi. Ini berarti semua tingkah laku dan tindak-tanduk perbuatan manusia Indonesia harus dijiwai dan merupakan pancaran dari Pancasila. Dalam sila ketiga, yang berbunyi persatuan Indonesia, hal ini menunjukkan bahwa masyarakat Indonesia harus menciptakan dan melahirkan rasa persatuan dan kesatuan bangsa Indonesia di atas perbedaan agama, ras, suku, dan golongan. Sikap rukun, sejatinya juga telah tertera dalam Pancasila. Khususnya pada sila ketiga, yakni persatuan Indonesia. Pancasila juga memberikan petunjuk kepada bangsa Indonesia untuk selalu mengedepankan sila rukun dan damai.

Prinsip kerukunan merupakan cermin dan kultur bangsa Indonesia yang semakin menegaskan bahwa bangsa Indonesia adalah masyarakat yang beretika dan mengedepankan nilai-nilai moral dan kerukunan antar umat manusia. Karena itu dengan mengedepankan prinsip kerukunan antar sesama ini, masyarakat Indonesia diajak menggunakan rasio dan logikanya, yang memiliki kehalusan dan hati nurani baik dalam menjalani hubungan dengan umat manusia, yang berdasarkan pada nilai-nilai Pancasila. Driyarkara menjelaskan bahwa untuk mencapai prinsip kerukunan bangsa, maka paradigma yang digunakan adalah selalu levens beschouwing. Pancasila harus diamalkan dalam kehidupan sehari-hari, dengan kata lain, Pancasila digunakan sebagai petunjuk arah semua kegiatan dan aktivitas hidup dan kehidupan di dalam segala bidang, politik, pindidikan, agama, budaya, sosial, dan ekonomi (Khamidah, 2015).

\section{Paparan Hasil Penelitian}

Lokasi Malang Selatan tepatnya di Dusun Bajulmati Kecamatan Gedangan Kabupaten Malang Provinsi Jawa Timur secara geografis terletak $112^{\circ} 35^{\prime} 213-112^{\circ} 39^{\prime} 453$ BT dan $8^{\circ} 14^{\prime} 483$ $-8^{\circ} 22^{\prime} 313$ LS. Adapun luasnya sekitar 130,55 km² (4,38\% luas Kabupaten Malang) dengan keadaan wilayah ketinggian dari permukaan laut: 0-6 M.
Secara umum letaknya berada pada posisi datar didominasi oleh kemiringan antara 0-3\%.

Kecamatan Gedangan terdiri dari 8 desa, 41 dusun, $101 \mathrm{RW}$ dan $363 \mathrm{RT}$, dengan 431 jiwa $/ \mathrm{km}^{2}$ kepadatan penduduknya. Jumlah penduduk yang ada di Kecamatan Gedangan sebanyak 67.638 jiwa. Jumlah tersebut dapat dirinci menurut pemeluk agama sebagaimana dapat diketahui bahwa jumlah penduduk menurut pemeluk agama, maka pemeluk agama Islam dengan jumlah 64.417 jiwa $(95,23 \%)$, pemeluk agama Hindu berjumlah 1.211 jiwa $(1,79 \%)$ pemeluk agama Budha berjumlah 1.162 jiwa (1,71\%) dan pemeluk agama Nasrani berjumlah 853 jiwa $(1,26$ \%) (Dok, 2018).

\section{Lembaga Pendidikan Harapan Bajulmati sebagai Role Model Kerukunan Antar Umat Beragama di Malang Selatan}

Berdasarkan hasil pengamatan dan wawancara terkait dengan masalah kebutuhan utama masyarakat Bajulmati adalah pendidikan. Melalui proses yang panjang dengan berusaha memberikan motivasi dan penyadaran terhadap masalah pendidikan di Bajulmati. Shohibul Izar telah berhasil menyadarkan masyarakat Bajulmati akan masalah yang dihadapi serta kebutuhan pendidikan yang harus terpenuhi melalui beberapa strategi yang digunakan, sebagaimana pendapat Mardikanto yang menyebutkan bahwa "strategi merupakan suatu rencana". Strategi sebagai suatu rencana memiliki makna bahwa hal tersebut merupakan pedoman atau acuan yang dijadikan landasan dalam melaksanakan kegiatan (Mardikanto, 2013).

Strategi yang digunakan untuk mencapai hal tersebut yaitu menggunakan strategi berbasis masalah dan kebutuhan. Strategi ini dijalankan bertujuan agar program yang dilaksanakan sesuai, tepat dan berjalan secara berkesinambungan. Cara yang ditempuh untuk menggali masalah dan kebutuhan tersebut yaitu dengan door to door dan memanfaatkan media pertemuan umum. Door to door yang dimaksud yaitu kegiatan identifikasi masalah dan kebutuhan dilakukan dengan mendatangi rumah-rumah warga. Menjalin hubungan baik melalui komunikasi personal sampai mendapatkan informasi. Melalui media pertemuan seperti tahlil, dan pengajian identifikasi masalah dan kebutuhan diperoleh.

Strategi kedua yaitu strategi yang didasarkan 
pada kepentingan masyarakat agar masyarakat dapat berkembang dengan menggunakan pendekatan bottom-up. Strategi ini bertujuan untuk mengembangkan masyarakat agar mampu bergerak atau action untuk mengubah hidupnya. Pencapaian tersebut perlu menggunakan analisis terhadap potensi, keinginan, masalah dan kebutuhan mereka. Analisis ini dilakukan agar masyarakat ikut berpartisipasi dan bertanggung jawab pada program yang dijalankan.

Ada lima macam strategi dalam mempengaruhi masyarakat yang dapat digunakan. Strategi pertama yaitu relief and welfare strategy yang mengutamakan kekurangan dan kebutuhan masyarakat seperti sandang, pangan, pendidikan. Strategi kedua yaitu small scale reliant local yang mengutamakan kesehatan penerapan teknologi tepat guna dan pembangunan infrastuktur. Strategi ketiga yaitu sustainable system development yang umumnya berkaitan dengan dampak pembangunan yang terlalu eksploitatif dan mengabaikan keberlanjutan. Strategi keempat adalah people movement yang dilakukan melalui pengorganisasian masyarakat, identifikasi masalah, dan kebutuhan lokal. Strategi ini tidak sekedar mempengaruhi kebijakan tapi mengharapkan terjadinya perubahan dalam pelaksanaannya. Strategi terakhir yaitu empowering people yang memperhatikan arti penting perkembangan, teknologi, persaingan, dan kerjasama. Strategi ini memperjuangkan ruang gerak yang terbuka terhadap kemampuan dan keberanian masyarakat dan pengakuan pemerintah terhadap inisiatif lokal (Mardikanto, 2013).

Dari Keseluruhan strategi di atas penerapan dalam pendekatan pada masyarakat di Dusun Bajulmati Kecamatan Gedangan Malang hanya menggunakan dua strategi. Strategi relief and welfare dan people movement. Strategi tersebut dijalankan dengan menggunakan pendekatan humanis dan persuasif.

Pendekatan humanis diperlukan dengan tujuan untuk mempermudah proses pelaksanaan strategi relief and welfare dan people movement. Kedatangan Shohibul Izar ke Bajulmati melakukan pendekatan dengan istilah "ngewongke uwong" yaitu mengandung makna bahwa siapapun orangnya patut untuk kita hargai dan hormati. Pendekatan ini berdampak pada keterbukaan, kenyamanan, dan komunikasi antara masyarakat. Melalui pendekatan tersebut dapat menjalankan proses identifikasi masalah dan kebutuhan.

Pendekatan kedua yaitu persuasif yang merupakan pendekatan melalui rayuan. Shohibul Izar, selain melakukan pendekatan secara humanis juga mengajak masyarakat tanpa paksaan dan cenderung mengharapkan kesadaran kesukarelaan. Sukarela dan sadar untuk mengungkapkan masalah dan kebutuhan masyarakat. Kedua pendekatan tersebut yang telah berhasil membawa masyarakat Bajulmati untuk menjalankan program sesuai dengan strategi yang telah direncanakan.

Setelah melalui proses tahapan di atas baik secara humanis dan persuatif maka model yang dilakukan Shohibul Izar, adalah dengan menggunakan pembelajaran pada lembaga pendidikan, hal ini dilakukan untuk menyadarkan masyarakat dengan sendirinya, bahwa pendidikan adalah suatu hal yang penting dalam membangun generasi anak bangsa agar lebih baik dalam masa depannya.

Sejak tahun 1989 pengembangan pendidikan merupakan tujuan utama yang digagas oleh Shohibul Izar, lembaga pendidikan pertama kali yang dibangun adalah TK Harapan, kemudian PAUD Bina Harapan, RA Tunas Harapan, TK Tunas Harapan dan SD Tunas Harapan di Goa Cina Bajulmati, dimana semua lembaga ini berada pada naungan Yayasan Sosial Harapan Bajulmati.

\section{TK Harapan}

TK ini dirintis tahun 1989 oleh Shohibul Izar dan Mahbub Junaidi yang merupakan adik kandung dari Shohibul Izar. Pada tahun 1994 tempat belajar terletak di samping tambak udang kemudian tahun 2007 dipindah ke tempat yang lebih tinggi karena sering terkena banjir dan akhirnya muncullah nama TK Gunung.

\section{PAUD Bina Harapan}

PAUD Bina Harapan mulai dirintis pada tahun 2011. Ide didirikannya PAUD ini berawal dari gagasan Shohibul Izar, yang ingin membuat pendidikan di Bajulmati lebih maju. Pendidikan ini untuk membentuk karakter dan pribadi yang baik. Bangunan ini dapat terselesaikan atas bantuan dari para donatur dan juga kerja keras gotong royong masyarakat Bajulmati. 


\section{TK Tunas Harapan}

TK Tunas Harapan merupakan pendidikan yang tergolong baru, dirintis oleh Shohibul Izar. Pada mulanya TK ini tidak memiliki tempat khusus untuk belajar. Letak sekolah ini berlokasi di ujung Kecamatan Sumbermanjingwetan yang berbatasan dengan Bajulmati Kecamatan Gedangan. Pada saat itu Shohibul Izar, melihat kerumunan anak kecil berjumlah enam anak yang sedang bermain di daerah Goa Cina, melihat kerumunan anak bermain dan tidak bersekolah maka shohibul Izar mempunyai gagasan untuk membangun TK Tunas Harapan di tempat tersebut.

\section{SD Tunas Harapan}

Bentuk pendidikan lainnya yaitu SD Tunas Harapan Goa Cina. Letaknya tepat disamping TK Tunas Harapan. Pada awalnya pendiriannya muridnya berjumlah 4 anak dan merupakan lulusan TK Tunas Harapan. Kondisinya sama dengan TK Tunas Harapan bahkan bahan ajar belum tersedia, tidak memakai jadwal ajar dan tidak memiliki buku panduan. Masyarakat sekitar menyebutnya dengan "SD Kecil".

Selain itu peserta didiknya juga terdiri dari berbagai agama, Islam, Kristen Hindu dan Buddha namun pendidikan yang dilakukan adalah dengan pendekatan persamaan derajat antar sesama, tidak membeda-bedakan antara murid yang satu dan lainnya, sehingga jalinan persaudaraan dan kerukunan terjalin dengan kuat. Dari pendekatan itulah maka lembaga pendidikan umum yang bernafaskan Islam mendapatkan simpati di kalangan masyarakat Bajulmati dari semua agama.

Pendidikan yang dilakukan tidak hanya di dalam kelas saja namun di luar kelas peserta didik diajarkan untuk memahami keindahan alam, dengan cara susur sungai, pengenalan tanaman mangrove sebagai penyokong paru-paru dunia, kegiatan ini dilakukan dalam wahana permainan anak yang didekatkatkan pada ke-Agungan ciptaan Tuhan. Pendekatan seperti ini dapat membangunkan cipta rasa dan pemahaman terhadap peserta didik yang menjadikan alam sebagai sahabat guna menjalani hidup dalam kehidupan sehari-hari.

Oleh karena itu lembaga pendidikan di Bajulmati dapat dijadikan sebagai role model kerukunan antar umat beragama, lembaga pendidikan yang berada di pelosok kecil dengan peserta didik yang terdiri dari agama Islam, Kristen, Hindu, dan Buddha hidup berdampingan dengan rukun dan damai.

\section{E. Kesimpulan}

Lembaga pendidikan merupakan sarana dalam pembentukan karakter dan perilaku peserta didik. Ada beberapa cara dapat dilakukan dalam mendapatkan simpati dari masyarakat yaitu dengan pendekatan secara humanis dan persuatif, kedua pendekatan dilakukan dalam rangka mendapatkan simpati pada masyarakat Bajulmati. Setelah masyarakat menyatu dalam satu persepsi maka didirikanlah lembaga pendidikan di antaranya TK Harapan, PAUD Bina Harapan, RA Tunas Harapan, TK Tunas Harapan, dan SD Tunas Harapan di Goa Cina Bajulmati. Lembaga Pendidikan ini dapat dijadikan role model dalam kerukunan antar umat beragama karena peserta didiknya terdiri dari berbagai agama, Islam, Kristen, Hindu, dan Buddha. Akan tetapi hidup secara rukun dan berdampingan. Proses yang diterapkan adalah pendidikan yang mengutamakan persamaan derajat dan tidak membedakan satu dengan yang lainnya. Pembelajaran tidak hanya di dalam kelas saja namun di luar kelas, peserta didik juga diajarkan untuk memahami keindahan alam, kegiatan ini dilakukan dalam wahana permainan anak yang didekatkatkan pada ke-Agungan ciptaan Tuhan.

\section{UCAPAN TERIMAKASIH}

Ucapan terima kasih penulis sampaikan kepada Badan Litbang dan Diklat Kementerian Agama RI yang memberikan kesempatan dan pengalaman bagi peneliti untuk menyusun artikel pada Jurnal Dialog Kementerian Agama dan terima kasih pula kepada tim reviewer yang memberi masukan dan penilaian terkait penulisan, sehingga dapat menambah pengalaman, wawasan dan pengetahuan yang sangat berharga bagi penulis. 
Abou El Fadl, K. (2014). Speaking in God's name: Islamic law, authority and women. Simon and Schuster.

Arif, M. (2014). Model kerukunan sosial pada masyarakat multikultural Cina Benteng (Kajian Historis dan Sosiologis). SosioDidaktika: Social Science Education Journal, 1(1), 52-63.

Daeli, D. O., \& Zaluchu, S. E. (2019). Analisis Fenomenologi Deskriptif terhadap Panggilan Iman Kristen untuk Kerukunan Antar Umat Beragama di Indonesia. SUNDERMANN: Jurnal Ilmiah Teologi, Pendidikan, Sains, Humaniora Dan Kebudayaan, 1(1), 44-50.

Fauzi, A. (2017). Agama, Pancasila dan Konflik Sosial di Indonesia. Lentera Hukum, 4(2), 122-130.

Halim, A., \& Jambi, F. U. I. S. T. S. (2015). Pluralisme dan Dialog Antar Agama. TAJDID, 14, 35-62.

Jauhari, M. I. (2017). Pendidikan Islam Berbasis Multikultural dan Konstruksi Sosial Pancasila. Proceedings of Annual Conference for Muslim Scholars, Seri 1, 385-392.

Khamidah, N. (2015). Model kerukunan antar umat beragama di Desa Kuripan Kecamatan Karangawen Kabupaten Demak. UIN Walisongo.

Kirom, S. (2011). Filsafat ilmu dan arah pengembangan Pancasila: relevansinya dalam mengatasi persoalan kebangsaan. Jurnal Filsafat, 21(2), 99-117.

Lestari, G. (2016). Bhinnekha Tunggal Ika: Khasanah Multikultural Indonesia Di Tengah Kehidupan SARA. Jurnal Pendidikan Pancasila Dan Kewarganegaraan, 28(1).

Luthfi, J. (2017). Model kerukunan antar umat beragama: studi inkulturasi antara umat Kristen dan Islam di Desa Nawangsari Kecamatan Weleri Kabupaten Kendal. UIN Walisongo.
Maftukhah, U. (2014). Kerukunan Antar Umat Beragama Dalam Masyarakat Plural (Studikerukunan. Skripsi Uin SUnan Kalijaga, 1, 62-88.

Mardikanto, T. (2013). Poerwoko dan Soebianto. Pemberdayaan Masyarakat Dalam Perspektif Kebijakan Publik, Bandung: Alfabeta.

Mawardi, M. (2015). Reaktualisasi Kerukunan antar Umat Beragama dalam Kemajemukan Sosial. SUBSTANTIA: Jurnal Ilmu-Ilmu Ushuluddin, 17(1), 55-66.

Muhtadi, B. (2019). Populisme, politik identitas, dan dinamika elektoral: mengurai jalan panjang demokrasi prosedural. Intrans Publishing.

Nata, A. (2001). Sejarah Pertumbuhan dan Perkembangan Lembaga-Lembaga Pendidikan Islam di Indonesia. Gramedia Widiasarana Indonesia bekerja sama dengan IAIN.

Nishimura, S. (1995). The development of Pancasila moral education in Indonesia. Japanese Journal of Southeast Asian Studies, 33(3), 303-316.

Nugrahani, F., \& Hum, M. (2014). Metode Penelitian Kualitatif. Solo: Cakra Books.

Raharjo, R., Armawi, A., \& Soerjo, D. (2017). Penguatan Civic Literacy Dalam Pembentukan Warga Negara Yang Baik (Good Citizen) Dan Implikasinya Terhadap Ketahanan Pribadi Warga Negara Muda (Studi Tentang Peran Pemuda HMP PPKn Demokratia pada Dusun Binaan Mutiara Ilmu di Jebres, Surakarta, Jawa Tengah. Jurnal Ketahanan Nasional, 23(2), 175-198.

Rahayu, M. (2017). Keragaman di Indonesia dan Politik Pengakuan (Suatu Tinjauan Kristis). Jurnal Pemikiran Sosiologi, 4(2), 1-18.

Rusydi, I., \& Zolehah, S. (2018). Makna Kerukunan Antar Umat Beragama Dalam Konteks Keislaman Dan KeIndonesian. Al-Afkar, Journal For Islamic Studies, 1(1, January), 170181.

Simon, A. N. (2017). PENGARUH ROLE MODEL GURU TERHADAP INTEGRITAS MORAL 
REMAJA. University of Muhammadiyah Malang.

Soesilo, Y. (2011). Gereja Dan Pluralisme Agama Dalam Konteks Di Indonesia. Jurnal Antusias, 1(2), 81-93.

Sofwan, R., Wasit, H., \& Mundiri, H. (2000). Islamisasi di Jawa: Walisongo, penyebar Islam di Jawa, menurut penuturan babad. Pustaka Pelajar.

Syarif, N. (2013). Teologi Kerukunan. Theology of Harmony), Pikiran Rakyat.

Widiastuti, W. (2013). Analisis SWOT Keragaman Budaya Indonesia. Jurnal Ilmiah Widya, 4(2).

Yewangoe, A. A. (2002). Iman, agama, dan masyarakat dalam negara Pancasila. Bpk Gunung Mulia.
Yusuf, I. (2010). Islamic theology of religious pluralism: Qur'an's attitude towards other religions. Prajñâ Vihâra, 11(1).

Zaluchu, S., \& Widjaja, F. (2019). A Phenomenology Approach: Religious Significance of Mandala in Ancient Nias Culture. Proceedings of the Proceedings of the 1st Seminar and Workshop on Research Design, for Education, Social Science, Arts, and Humanities, SEWORD FRESSH. 
